\title{
Status of Migration and Its Perceived Effects in Khopasi, Kavrepalanchowk District: A Descriptive Cross-Sectional Study
}

\author{
Bhattarai $\mathbf{N}^{1}$, Manandhar $\mathbf{N}^{1}$, Shrestha $\mathbf{S}^{1}$, Twanabasu $\mathbf{R}^{1}$, Shah $\mathbf{S}^{1}$, Amatya $\mathbf{I}^{1}$, Jyoti $\mathbf{S}^{1}$, Joshi SK \\ ${ }^{1}$ Department of Community Medicine, Kathmandu Medical College, Sinamangal, Kathmandu, Nepal
}

\section{ABSTRACT}

Introduction: Labor migration has become a means to make ends meet for low-income countries. It plays a key role to provide employment opportunities and has helped in the improvement of the standard of living. With the alarming rise of migrating workers, it becomes important to acknowledge the effects of migration on both the migrant workers in the destination country as well as families left behind at the place of origin. The objective of this study was to find out the status of migration of population in Khopasi village and their attitude towards the effects of migration on families left behind.

Methods: A descriptive cross-sectional study was conducted among 256 residents of Khopasi, Kavrepalanchowk district from 10-15th November 2019. Participants were interviewed using a semi-structured questionnaire to assess the status of migration of immediate family members as well as the attitude towards migration and its effects.

Results: The prevalence of migrant workers was $39.8 \%$. The process of migration was assisted by their migrated relatives $59(19.1 \%)$ and by foreign employment agencies $30(12.92 \%)$. The expenses for migration were managed by bank loan 34 (33.34\%). Among102 migrant workers, 54(52.9\%) are still working abroad whereas $48(47.1 \%)$ have returned to Nepal. The main reason for migrant workers to go abroad was unemployment 59 $(57.8 \%)$ in Nepal. Out of 102 who migrated, most of them $39(38.23 \%)$ have spent $1-3$ years abroad while 76 $(68.6 \%)$ send remittance regularly to their family members at home around 1-3 lakhs/year. Among all the migrant worker $37(36.27 \%)$ reported some form of disease and disability. There was a positive attitude toward family and the country's economy but the overall attitude towards migration was negative.

Conclusion: In this study, remittance sent by migrant workers to their families was not adequate as there were no visible financial benefits and negative health consequences were also present. There are other impacts of migration like broken families, separation, difficulty in the rearing of children, mental health of elderly were seen on the families left behind. Various studies are required to further analyze the impact of migration other than remittance.

Key words: Attitude, Effect of migration, Families left behind, Migrant workers.

\section{Introduction}

A migrant is a person who moves away from his or her place of usual residence, whether within a

DOI: https://doi.org/10.3126/ijosh.v10i2.33362

Date of submission: 02.09.2020

Date of acceptance: 28.11 .2020

\section{Corresponding Author}

Dr. Nikita Bhattarai

Department of Community Medicine,

Kathmandu Medical College,

Sinamangal, Kathmandu, Nepal

Tel: +977 9851254281

Email: dr.nikitabhattarai@gmail.com

ORCID ID: https://orcid.org/0000-0003-4036-5007 country or across an international border, temporarily or permanently and for various reasons. ${ }^{1}$

Migration is perceived as an escape from poverty and unemployment in developing countries including Nepal. ${ }^{2.3}$ People are struggling with day-to-day needs have led to an increase in both legal and illegal migration. ${ }^{4}$ Labor migration in Nepal started formally in 1990 as an opportunity for employment and it became more influential since 2000 with the rise of Maoist insurgency and it has been growing exponentially ever since. $^{5}$

\section{cc) (i) (8)}

This journal is licensed under a Creative Commons AttributionNon Commercial 4.0 International License. 
National Health Demography survey (2016) reported that $47 \%$ of the household had at least one person who had migrated in the last 10 years in Nepal. ${ }^{6}$ Approximately five million people have migrated to various countries such as Qatar, Malaysia, United Arab Emirates, Saudi Arabia, Korea, India, etc. from Nepal. ${ }^{7}$ The open border with India makes it difficult to estimate yet it is expected that about one million people are working there. ${ }^{8}$

The decision for migration is driven by the attraction of remittance. ${ }^{9}$ Migration can have physical, mental, emotional health impact affecting the overall wellbeing of both the migrant and their family members. ${ }^{10}$ Migration has been a source of survival, for better access to nutrition, health care which ultimately led to the improvement in the standard of living. It has also played a crucial role in poverty alleviation. ${ }^{11}$

Migration also has its fair share of negative consequences which has to be handled by both the migrant worker as well as the family members. The one who migrates has to endure the discriminatory behavior at the workplace, employer's deception, false assurance of salary as well as of the working condition. Some migrant workers had also met with accidents whereas others had to deal with health hazards due to working in extreme weather conditions..$^{12}$ It has also led to the breaking down of social structure including increased disparities with the wife and many also have been separated. ${ }^{13}$ There are serious implications in the behaviors of children as well as on the mental health of the elderly parents. ${ }^{14,15}$ Another sector which has been affected is agriculture. With so many workers shifting offshore and urbanization, people are becoming increasingly separated from farming which leads to increased wage rates as well as decrease production. ${ }^{16}$

\section{Methods}

A descriptive cross-sectional study was conducted in Khopasi, Kavrepalanchowk district from 10-15 November 2019. Kavrepalanchowk district was taken purposively as it is one of the top 10 districts for migration in Nepal. Using convenient sampling a total of 256 respondents were included in the study who were 18 years and older. Only one person from each household who were residing in Khopasi were included in the study.

The semi-structured questionnaire was developed by the researchers. The Questionnaire consisted of socio-demographic information, the status of migration details, and attitude regarding effects on people left behind including children, spouses, elderly, development, and current migration trend in Nepal. The status of the country migration details was taken only if the family member had undergone migration. The interview was conducted only after informed consent was obtained from the participants and confidentially was maintained. The ethical approval was taken from the Institutional Review Committee (IRC) of Kathmandu Medical College.

Collected data were entered into Microsoft Excel and analysis were done using Statistical Package for Social Sciences (SPSS) software. Attitude towards migration was scored from 5 to 1 according to a strongly positive attitude, positive attitude, neutral, negative attitude, and strongly negative attitude. Then all the positive and negative attitudes were recorded as 1 and 0 respectively. Then, the total score was calculated by adding the score of 19 questions. Then, the attitude was categorized into poor (below 50 per cent of the total score) and good (more than or equal to 50 per cent of the total score).

\section{Results}

Among the total respondents (256) interviewed, 66 $(25.8 \%)$ were from the age group 35-44 years. The mean age was 43.57 years with a standard deviation was 15.17 years. Males were $120(46.9 \%)$ and females were $135(53.1 \%)$. The majority of respondents were Hindu 240 (93.8\%) by religion and Brahmin 99 (38.7\%) by ethnicity, $239(93.4 \%)$ were married and $63(24.6 \%)$ had completed their primary level of education. ( Table 1)

The prevalence of migrant workers was $39.8 \%$ among them, the majority were male $78(76.5 \%)$ and female were $24(23.5 \%)$. Among the family members left behind $28(12.2 \%)$ consisted of only parents and $23(10 \%)$ were parents' wives and children. Both parents $10(3.9 \%)$ left their children for migration. Among the people who migrated, $39(15.2 \%)$ had have spent 1-3 years abroad while 18 ( $7 \%$ ) have spent more than 9 years.

The majority of respondents 59 (57.84\%) opined that unemployment was the main reason for going abroad. (Figure 1) The expenses for migration were managed by the bank loan $34(33.34 \%)$ and borrowing money from the friend/ family $29(28.6 \%)$. The process of 
migration was done with the help of relatives living abroad for $52(19.1 \%)$ and $30(12.9 \%)$ was through foreign employment agencies. Out of 102 migrant workers, $70(68.62 \%)$ respondents sent money home with an average of 1-3 lakhs/year. Out of those people who migrated, $12(4.7 \%)$ were not in contact with the family members. Among all the people who migrated, $37(36.27 \%)$ have reported some form of either disease or disability whereas $2(0.8 \%)$ reported being cheated by the foreign employment agencies.

Regarding the status of the returnees, out of 102 migrant workers who migrated, $48(47 \%)$ had returned to Nepal. The reason for the return was contract expiration (Figure 2). The majority of migrant workers $25(52 \%)$ spent 3 years abroad and only 2(4.1\%) people stayed for over 12 years before returning to Nepal.

Among the total respondents, positive attitude was found towards the effect of migration on children and the country's economy whereas negative attitude was found towards the effect of migration on women and family (Table 2). Men have a good attitude whereas women have a poor attitude towards migration. (Figure 3)

Table 1: Respondent's Socio-demographic details

\begin{tabular}{llc}
\hline Variable & & No. of respondents( \%) \\
\hline Gender & Male & $120(46.9)$ \\
& Female & $136(53.1)$ \\
& $15-24$ & $28(10.9)$ \\
& $25-34$ & $51(19.9)$ \\
Age & $35-44$ & $66(25.8)$ \\
& $45-54$ & $44(17.2)$ \\
& $55-64$ & $38(14.8)$ \\
& $65-74$ & $21(8.2)$ \\
& $75-85$ & $8(3.1)$ \\
& Without any formal education & $61(23.8)$ \\
& Can read and write & $28(10.9)$ \\
Educational & Primary level & $63(24.6)$ \\
Level & Secondary level & $51(19.9)$ \\
& Intermediate Level & $39(15.2)$ \\
Marital & Bachelors & $10(3.9)$ \\
Status & Masters & $4(1.6)$ \\
\hline
\end{tabular}

Table 2: Attitude towards the effect of migration on various aspects

\begin{tabular}{cccccc}
\hline Attitude & Effect on Women & Effect on Children & Effect on family Effect on country & $\begin{array}{c}\text { Overall effect on } \\
\text { migration }\end{array}$ \\
\hline Positive & $102(39.85)$ & $162(63.29)$ & $99(38.67)$ & $131(51.17)$ & $121(47.27)$ \\
Negative & $154(60.15)$ & $94(36.71)$ & $157(61.33)$ & $125(48.83)$ & $135(52.73)$ \\
\hline
\end{tabular}




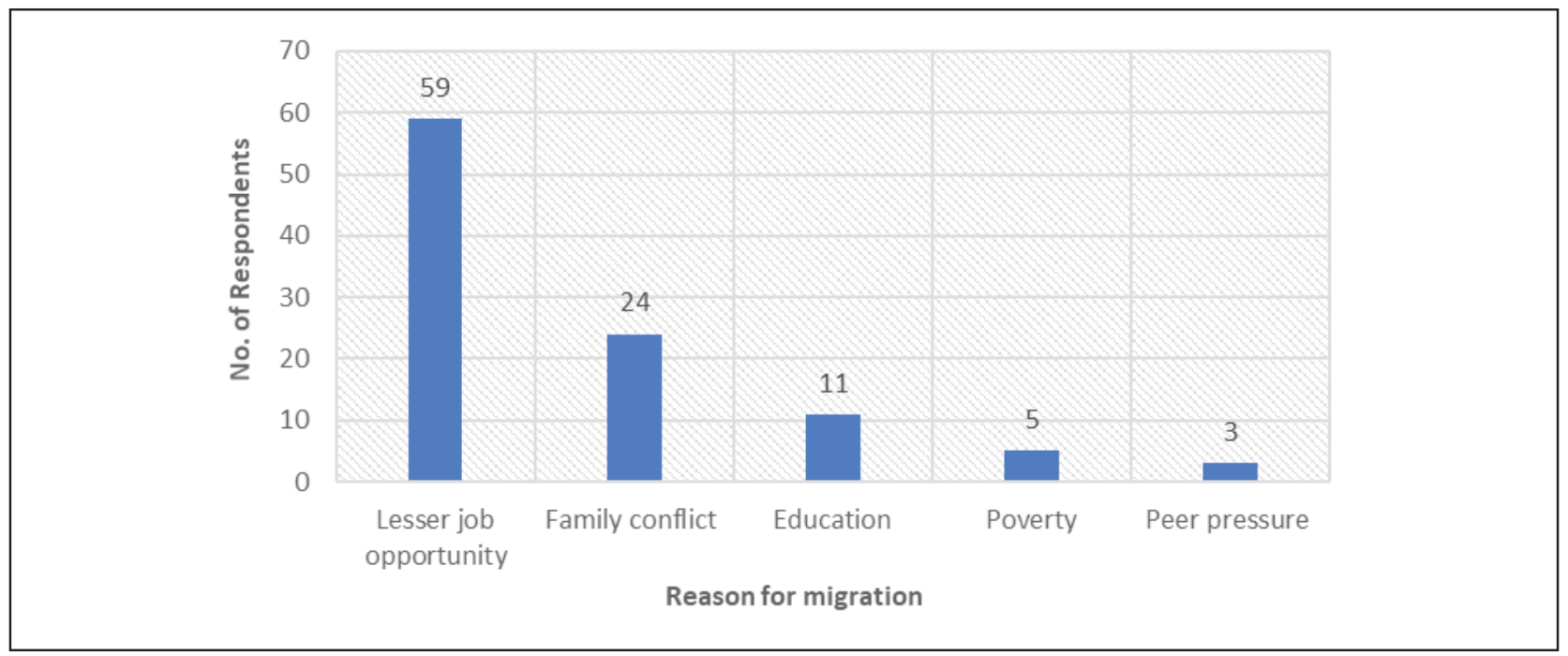

Figure 1: Reason for migration

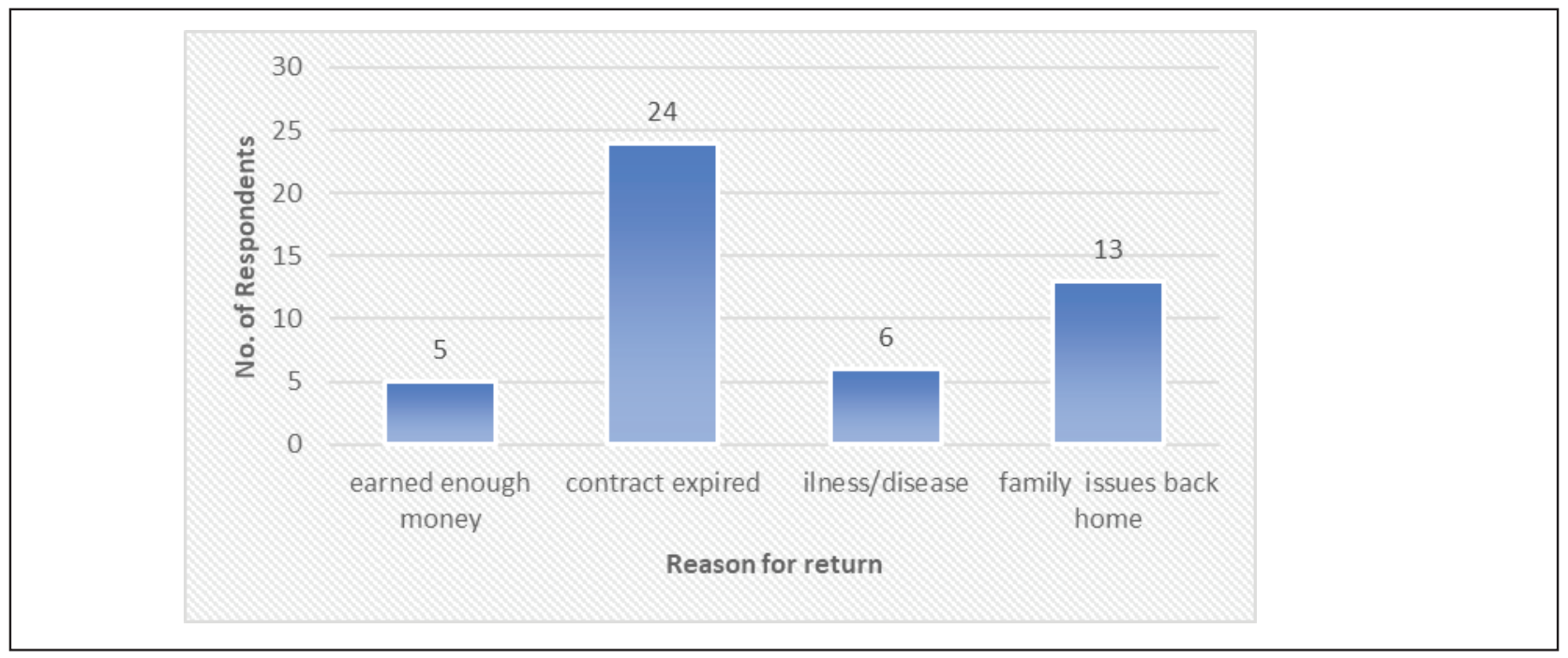

Figure 2: Reason for Return of migrant workers

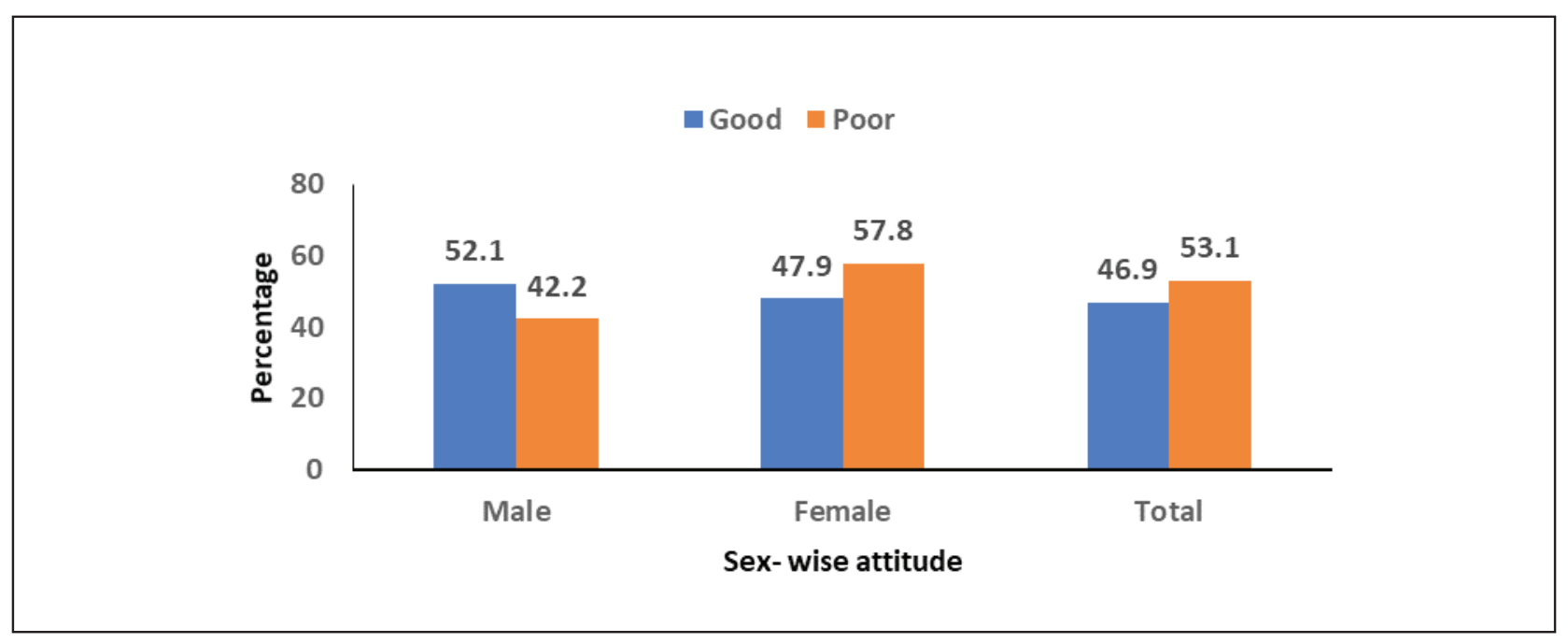

Figure 3: Sex wise scoring of attitude as expressed by the respondents 


\section{Discussion}

This study showed that nearly three-fifths (61.3\%) of respondents agreed that migration of husbands compelled their wives to take all responsibilities. This was similar to the study conducted in Nepal, 2009, that when husbands were away, their wives not only continued to rear the children and took care of the usual household chores but often also filled in for absent husbands on family plots or enterprises. ${ }^{17}$ More than two-fifths of respondents $(41.1 \%)$ disagreed that women feel more independent after husband migrated. This finding was in contrast to another study done in Nepal (2012 and 2020) which reported that wives of the migrant workers had a greater role in making household decisions than wives of non-migrant workers. ${ }^{18,19}$ In the present study, more than half of the female respondents $(57.8 \%)$ had a poor attitude towards migration. Female heads of agricultural households have a particularly hard time when the male counterpart is not available for various agricultural tasks. ${ }^{17}$ More than half of the respondents $(53.5 \%)$ replied that migration led to broken families, divorce, and separation. Other studies done in Nepal (2019) and China (2015) had also reported conflicting spousal relations including divorce and misuse of money by spouses left behind. ${ }^{20,21}$

Nearly three-fifths of respondents $(57.03 \%)$ stated that child felt lonely and distant and half of them (50.78\%) felt that they had a poor performance in the school due to lack of supervision when their parents were away. On the contrary, a study done in Mexico, 2016, found that migrant families were utilizing modern healthcare facilities and educating children in better schools. ${ }^{22}$ Another study in 2016 in Sri Lanka showed that the effects of parental migration were heterogeneous. ${ }^{23}$

The effect of male migration had important implications for women's social status as well as increased physical hardship in women which affected women's health both physically and mentally. ${ }^{19}$ It could also influence outcomes for other household members, particularly children. ${ }^{24}$

More than two-fifths $(43.4 \%)$ of respondents agreed that the parents of migrant workers felt lonely and depressed. Similar results were found by other studies done in Nepal (2014 and 2018) and Britain (2009) reported negative consequences for aging parents such as loneliness, isolation, and the loss of basic economic support. ${ }^{14,25,26}$ More than two-fifth (42.6\%) of respondents disagreed that the health of parents would be better due to an increase in health-seeking behavior which contradicted the finding from a study in Nepal, 2011, which stated out-migration was independently associated with higher utilization of health facilities after receiving money from their migrant children. ${ }^{27}$

Half of the respondents $(51.17 \%)$ had a poor attitude towards the effects of migration on the country's economy and two-fifth of the participants $(43.8 \%)$ agreed that remittance would increase their standard of living.

Regarding the impact of remittances on the economic growth of the country, the evidence was ambiguous. A study reported that remittances boosted prospects for economic growth while other studies suggested that the impact of remittances on growth and investment was positive but relatively small. ${ }^{28,29,30}$

The present study showed that $51.6 \%$ of people felt that migrant workers would return home if employment opportunities were provided to them. The proper channelization of remittance should be the top priority as migration in Nepal contributed to $27.7 \%$ in GDP in $2014 / 15 .{ }^{31}$ The government of Nepal is also trying to improve the condition by providing loans to migrant workers who have returned after migration to overcome the overdependence on remittance and dissociation from its negative impacts. ${ }^{7}$

\section{Conclusion}

This study concluded the prevalence of migrant workers was $39.8 \%$. Unemployment was the main driving force. They had invested a lot to undergo migration, including bank loan or by borrowing of money whereas only $68.62 \%$ sent money home with an average of $1-3$ lakhs/ year. Out of all the people who migrated, $47 \%$ returned, and the main reason for returning was the expiration of the contract. The lack of employment opportunities in Nepal is creating migration as a compulsion rather than a choice. A positive attitude was found towards the effect of migration on children and the country's economy whereas negative attitude was found due to migration on women and family.

\section{Limitation}

There are multiple reflections that we can share about the effects of migration on the families left behind. However, it is important to note that we cannot make 
generalizations, rather it is necessary to consider the social, family, and community conditions that correspond to the diversity of experiences of people in communities.

\section{Recommendation}

The study indicated that migrant workers health should be a national priority agenda so that measures could be taken to ensure the health and well-being of migrant workers and their families left behind. So, further management of employment opportunities in Nepal could reverse the trends of migration as well as be an encouragement to migrant workers for returning to their home country.

\section{Acknowledgement}

We would like to thank and appreciate all the participants for their valuable contribution to this study.

\section{References}

1. International Organization for Migration. Who is a migrant? International Organization, Geneva. Switzerland. Available from: http://iom.int/who-is-amigrant.

2. Simkhada, P, Prescott, GJ. Health problems of Nepalese migrants working in three Gulf countries. BMC International Health and Human Rights. 2011(3): 1-10. Available from: https://doi.org/10.1186/1472698X-11-3.

3. Central Bureau of Statistics. (2012). National population and housing census 2011. Kathmandu, Nepal: Central Bureau of Statistics. Available from: http://cbs.gov.np/image/data/Population/ National\%20Report/National\%20Report.pdf

4. Bhandari P. Relative Deprivation and Migration in an Agricultural Setting of Nepal. Population and Environment. 2004 May;25(5):475-99. Available from: www.jstor.org/stable/27503897

5. Migration in Nepal.Country profile 2019. International Organization of migration. Kathmandu Nepal. Available from: https://publications.iom.int/system/ files/pdf/mp_nepal_2019.pdf

6. Nepal Demographic and Health Survey 2016. Ministry of Health Ramshah Path, Kathmandu Nepal.2017. Available from: https://www.dhsprogram.com/pubs/ pdf/fr336/fr336.pdf)

7. Ministry of Labour and Employment, Government of Nepal. Labour Migration for Employment: A Status Report for Nepal: 2015/2016-2016/2017; Ministry of Labour and Employment: Kathmandu, Nepal, 2018.

8. Sharma JR. Marginal but modern: Young Nepali labour migrants in India. YOUNG 2013; 21(4):34762. https://doi.org/10.1177/1103308813506307.

9. Velayutham S, Wise A. Moral economies of a translocal village: obligation and shame among South Indian. Global Networks.2005 February:5(1). Available from: https://doi.org/10.1111/j.14710374.2005.00106.x.

10. Carballo M, Divino JJ, Zeric D. Migration and health in the European Union. Tropical Medicine and International Health 2002;3(12). Available from:

https://doi.org/10.1046/j.1365-3156.1998.00337.x

11. Bohra P, Massey DS. Processes of Internal and International Migration from Chitwan, Nepal. Int Migr Rev. 2009;43(3):621-51. doi:10.1111/j.17477379.2009.00779.x

12. Thapa N, Paudel M, Guragain AM, Thapa P, Puri $R$, Thapa $P$ et. al .Status of migration and socioreproductive impacts on migrants and their families left behind in Nepal. Migration and Development. 2019. Available from : https://doi.org/10.1080/21632 324.2019.1567097.

13. Gao Y, Li LP, Kim JH, Congdon N, Lau J, Griffiths $S$. The impact of parental migration on health status and health behaviors among left behind adolescent school children in China. BMC Public Health. 2010;10(1):56. Available from: https://doi. org/10.1186/1471-2458-10-56

14. Shrestha L. Geriatric Health in Nepal: Concerns and Experience. Nepal Medical College J. 2012;144-8

15. Chen F, Liu H, Vikram K, Guo Y. For better or worse: the health implications of marriage separation due to migration in rural China. Demography. 2015;52(4):1321-43. Available from: https://link. springer.com/article/10.1007/s13524-015-03999\#citeas.

16. Sunam RK, McCarthy JF. Reconsidering the links between poverty, international labour migration, and agrarian change: critical insights from Nepal. The Journal of Peasant Studies. 2016;43(1):39-63. Available from: http://dx.doi.org/10.1080/03066150.2 015.1041520.

17. Gartaula HN. International migration and local development in Nepal. Contributions to Nepalese Studies. 2009;36(1):37-65. Available from: https:// www.researchgate.net/profile/Hom_Gartaula2/ publication/40791945_International_Migration_and_ Local-Development-in-Nepal.pdf

18. Aryal N, Regmi P, Van ET, Trenoweth S, Adhikary P, Simkhada P. The Impact of Spousal Migration on the Mental Health of Nepali Women: A Cross-Sectional Study. International Journal of Environmental Research and Public Health. 2020.17(4):1292. Available from: https://www.researchgate.net/ 
publication/339360349_The_Impact_of_Spousal_ Migration_on_the_Mental_Health_of_Nepali_ Women_A_Cross-Sectional_Study

19. Maharjan A. Bauer S, Knerr B.Do Rural Women Who Stay Behind Benefit from Male Out-migration? A Case Study in the Hills of Nepal. Gender, Technology and Development.2012;16(1):95-123. Available from: https://www.tandfonline.com/action/showCitFo rmats?doi=10.1177\%2F097185241101600105

20. Thapa N, Paudel M, Guragain AM, Thapa P, Puri $R$, Thapa $P$ et. al. Status of migration and socioreproductive impacts on migrants and their families left behind in Nepal. Migration and Development. 2019. Available from: https://doi.org/10.1080/21632 324.201.1567097.

21. Chen F, Liu H, Vikram K, et al. For better or worse: the health implications of marriage separation due to migration in rural China. Demography. 2015;52(4):1321-43. Available from: https://link. springer.com/article/10.1007/s13524-015-0399-9

22. Ovando SPD, Guzman EF, Resendiz EG. EFFECTS OF MIGRATION ON CHILDHOOD IN GUANAJUATO, MEXICO. European Journal of Business and Social Science.2016;5(5):1-14.

23. Sarma VJ, Parinduri RA. What happens to children's education when their parents emigrate? Evidence from Sri Lanka. International Journal of Educational Development.2016;46:94-102.

24. Lokshin M, Glinskaya E. The Effect of Male Migration on Employment Patterns of Women in Nepal. The World Bank Economic Review Advance Access published 2009. World Bank group. Washington, DC, United States of America

25. Abas MA, Punpuing S, Jirapramukpitak T, Guest $\mathrm{P}$, Tangchonlatip $\mathrm{K}$, Leese $\mathrm{M}$, et al. Rural-urban migration and depression in ageing family members left behind. British Journal of Psychiatry. 2009;195(1):54-60.

26. Ghimire S, Singh DR, Nath D, Jeffers EM, Kafle M. Adult children migration and wellbeing of left behind Nepalese Elderly Parents. Journal of Epidemiology and Global Health. 2018;8(3):154-61.

27. Adhikari R, Jampaklay A, Chamratrithirong A. Impact of children's migration on health and health careseeking behaviour of elderly left behind. BMC Public Health. 2011;11(143). Available from: http://www. biomedcentral.com/1471-2458/11/143.

28. Fajnzylber, P, López, HJ. Close to home: The development impact of remittances in Latin America. 2007. Washington, DC: World Bank group. http://documents.worldbank.org/curated/ en/869061468266372115/Close-to-home-thedevelopment-impact-of-remittances-in-LatinAmerica.

29. Ortega F, Peri G. The cause and effects of international migration : evidenced from OECD countries 19802005. The national bureau of economic research. 2009.1050 Massachusetts Avenue Cambridge. United States of America

30. Dahal P. The impact of remittances on economic growth in Nepal: an analysis of a significant basis of development. Asia Pacific Journal of Public Administration, 2014; 36(4): 261-82. Available from: http://dx.doi.org/10.1080/23276665.2014.975908.

31. Gerritsen A, Bocquier P, White M, Mbacké C, Alam N, Beguy $D$, et. al. Health and demographic surveillance systems: contributing to an understanding of the dynamics in migration and health. Global Health Action.2013;(6)1. Available from: https://www. tandfonline.com/doi/full/10.3402/gha.v6i0.21496. 